\title{
Response of macrofauna to drifting tidal sediments
}

\author{
R. Zühlke \& K. Reise \\ Biologische Anstalt Helgoland, Wattenmeerstation Sylt; D-25992 List, \\ Federal Republic of Germany
}

\begin{abstract}
The effect of hydrodynamically-mobilized sediment on abundance and vertical distribution of macrobenthic fauna was studied in Königshafen, a sheltered tidal bay at the northern end of the Island of Sylt (North Sea). Sediment drift tended to increase from high towards low tide level, while abundance of nearly all species decreased (with the polychaete Spio filicornis as a notable exception). To test whether this decrease could be attributed to water currents affecting sediment stability, experimental flumes with funnels at both ends were set up to enhance sediment mobility by increasing tidal current velocities. Abundance and vertical distribution of fauna inside and outside the flumes were compared. Responses of individual species depended on their vertical position in the sediment, and resembled those observed along the gradient of sediment drift between high and low tide levels. Mainly juveniles of Pygospio elegans, Scoloplos armiger, Hydrobia ulvae and Macoma balthica, and the small polychaete Microphthalmus sczelkowii were washed out of the sediment. No effect of increased erosion inside the flume was found on the numbers of Capitella capitata and the oligochaetes Tubificoides benedii and T. pseudogaster. These oligochaetes probably migrated downwards with increasing erosion in the flumes. Numbers decreased in the upper $\mathrm{cm}$ and tended to increase below. A storm had a similar effect on oligochaete vertical distribution, while under conditions of permanently high sediment mobility near low tide level, these species were rare or absent. It is concluded that even under sheltered conditions, differential degrees of sediment mobility may have effects on the zonation of the tidal flat macrofauna.
\end{abstract}

\section{INTRODUCTION}

Hydrodynamic forces mobilize sediment in shallow marine habitats. In the Wadden Sea, the dynamics of sediments have been described by Postma (1982) and Ehlers (1988). Sediment movement is of central interest when investigating factors controlling benthic communities. In wave- and current-exposed areas, high sediment dynamics are regarded as being responsible for large-scale distribution patterns of macrofauna (Dörjes, 1976; Croker, 1977; Oliver et al., 1980; Dexter, 1984). Sediment shift during storms or hurricanes has been reported to cause diminished species and individual densities (Ansell et al., 1972; Rachor \& Gerlach, 1978; Yeo \& Risk, 1979; Rhode, 1985). In wave-protected areas, on the other hand, biogenic sediment disturbances have been shown to affect macrofaunal composition and distribution (Rhoads \& Young, 1971; VanBlaricom, 1982; Grant, 1983; Reise, 1985; Brey, 1991). The aim of this investigation is to test whether in such biogenically reworked sediments, hydrodynamic forces still have effects on abundance and distribution of the sediment infauna. Investigations were carried out in the bay of Königshafen in the northern Wadden Sea, where the sediment has been described as stable relative to other tidal flats in this region (Austen, 1992). Despite being characterized on the whole as a sheltered bay, a gradient of increasing sediment stability was 
detected from the low to high intertidal zone. The macrofaunal distribution along this gradient was studied, as well as species responses to experimentally-enhanced erosion.

\section{MATERIAL AND METHODS}

\section{Study site}

Sampling and field experiments took place on Möwenbergwatt, a tidal flat south of a sharp bend of the tidal inlet of Königshafen (Fig. 1). Sediment on this intertidal sandflat is relatively coarse due to aeolian input of sand from surrounding dunes. Grain size decreases with increasing distance from this sand-supplying area (Austen, 1992). Median particle diameter was $0.34 \mathrm{~mm}$ at high, $0.28 \mathrm{~mm}$ at mid and $0.22 \mathrm{~mm}$ at low tide level. Mean organic content ranged between $0.36 \%$ and $0.51 \%$, and water content of the sediment varied between $18.6 \%$ and $21.6 \%$ throughout the area.

\section{Measurement of sediment movement}

Depth of sediment disturbance was studied along a transect from high to low tide level using stained sand tracer (Ingle, 1966; Runte, 1989). Sand stained red was mixed with a solution of di- and polysaccharides to form a malleable paste, which was then

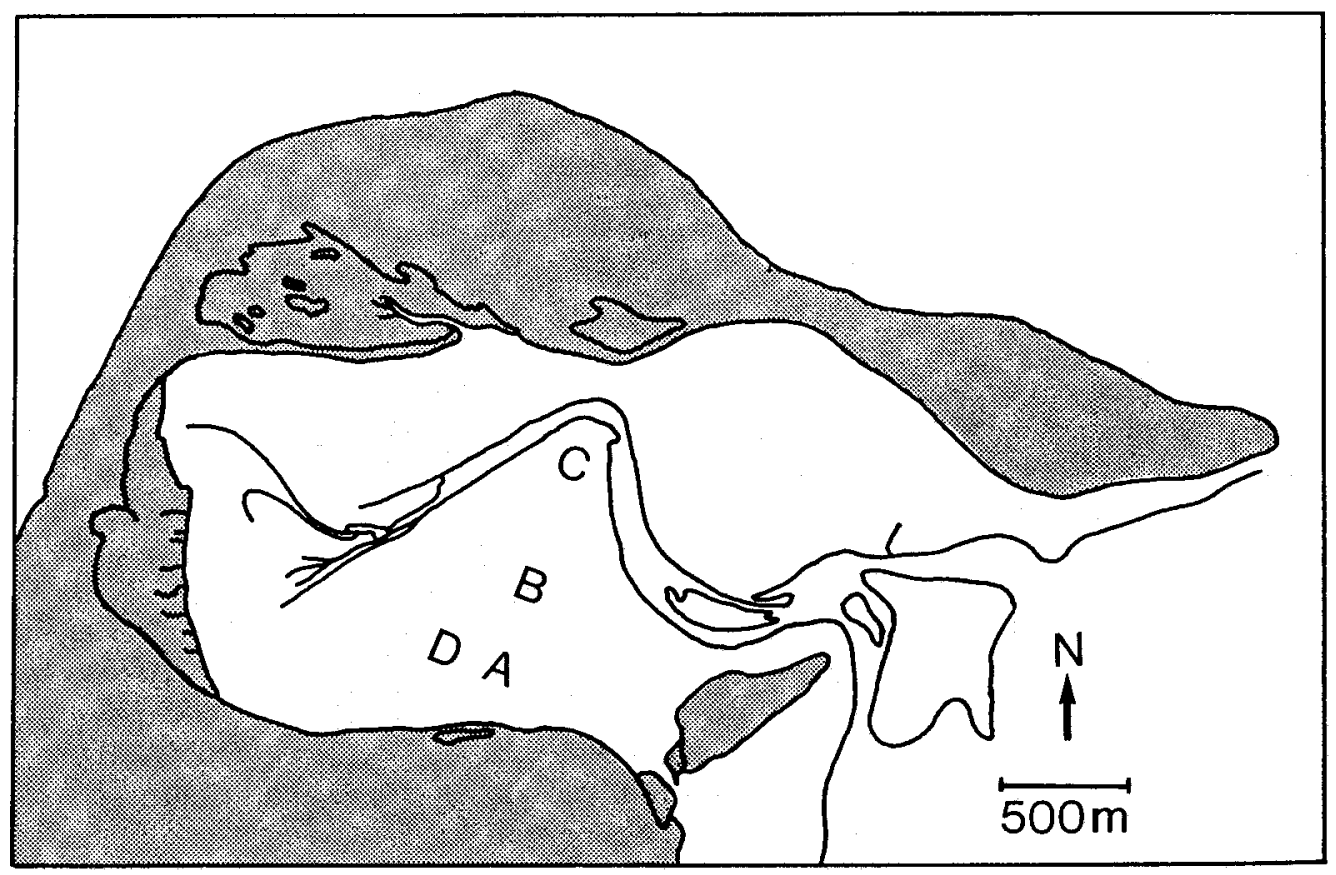

Fig. 1. Map of Königshafen Bay with transect sites (A, B, C) and sites of flume experiments (A, D). A: most stable sediment, flume experiment; $B$ : moderately mobile sediment; $C$ : mobile sediment; $D$ : flume experiment only. Area above mean high tide level is shaded; extreme high tide and mean low. tide levels are indicated 
shaped into columns 5 or $10 \mathrm{~cm}$ long and $1 \mathrm{~cm}$ in diameter and dried at $50^{\circ} \mathrm{C}$. Once inserted vertically into the sediment, the binding components dissolved quickly to leave a column of stained sand in the sediment. Hydrodynamical forces reaching critical erosion velocity mobilized bedform sediment as well as tracer particles. Dyed sand was re-cored after varying time spans ( 1 to 28 days) and the depth of disturbance was calculated as the difference between initial and final length of the tracer. Of 12 investigated stations, three representing a gradient relating to depth of disturbance were chosen as sample sites (Fig. 1). There the migration rate of sediment was estimated. A corer (surface area $23 \mathrm{~cm}^{2}$ ) was pushed to a depth of $2 \mathrm{~cm}$ and removed. Dyed sand was used to fill the hollow. After two tides, the distance between the visible trail end and the centre of the stained sand was measured. If the stained sand area could not be relocated, it was presumed to have been entirely dispersed. Tracer sand differed from bedform sediment in terms of organic content and porosity, and presumably the stained sand was less cohesive and therefore more mobile than the ambient sediment. Furthermore, a visual assessment as to where a trail tapers off is obviously a subjective judgement rather than an objective measurement. However, the results allowed a qualitative assessment of local sediment mobility.

\section{Faunal distribution}

Six samples of $100 \mathrm{~cm}^{2}$ surface area and $10 \mathrm{~cm}$ depth were collected at each of the three stations in September and November 1991. To determine the vertical distribution of the fauna, cores were partitioned immediately into 5 horizons: 0-1, 1-2, 2-3, 3-5, 5-10 cm. Macrofauna was extracted from the samples by a shaking-decantation procedure. Organisms of the upper 4 fractions were collected on a $0.25-\mathrm{mm}$ mesh while the $5-10 \mathrm{~cm}$ horizon was sieved through a $0.5-\mathrm{mm}$ screen. The wider mesh was adopted because previous studies showed that organisms passing a $0.5-\mathrm{mm}$ mesh but being retained by a $0.25-\mathrm{mm}$ mesh are not encountered below $5 \mathrm{~cm}$ depth. The unpreserved organisms were subsequently identified to the species level. Densities of the polychaete Arenicola marina were estimated by counting fecal casts in a $50 \times 50 \mathrm{~cm}$ metal frame, which was randomly placed at least eight times at each location in October and November.

\section{Erosion experiment}

Erosion experiments were carried out in stable sediment areas in the upper intertidal (Fig. 1: site A, D). Four flumes with funnel-shaped exits were designed to increase nearbottom tidal currents (Fig. 2). As a result, sediment mobility within the flumes was enhanced. Each flume was $2.5 \mathrm{~m}$ long, $20 \mathrm{~cm}$ high, $70 \mathrm{~cm}$ wide and consisted of two water-proof wooden walls which were inserted $7-10 \mathrm{~cm}$ deep into the sediment. To stabilize the walls, stakes were hammered into the ground to a depth of $50 \mathrm{~cm}$. Stakes and walls were screwed together. Funnels were constructed with plastic foil connected to stakes. They were $20 \mathrm{~cm}$ high, each side of the funnel 2.5 to $3 \mathrm{~m}$ long and the opening 2.5 to $3 \mathrm{~m}$ wide. Flumes were orientated to the prevailing direction of the tidal current.

Flow speed was determined $5 \mathrm{~cm}$ above the sediment by a Marsh-McBirney Portable Water Current Meter (Model 201 D). Depending on actual current speed, the velocity was up to twice as high in the flumes than in the surrounding area. Acceleration of currents was highest when the water level was $20 \mathrm{~cm}$ or less. This led to erosion of up to $4 \mathrm{~cm}$ of 


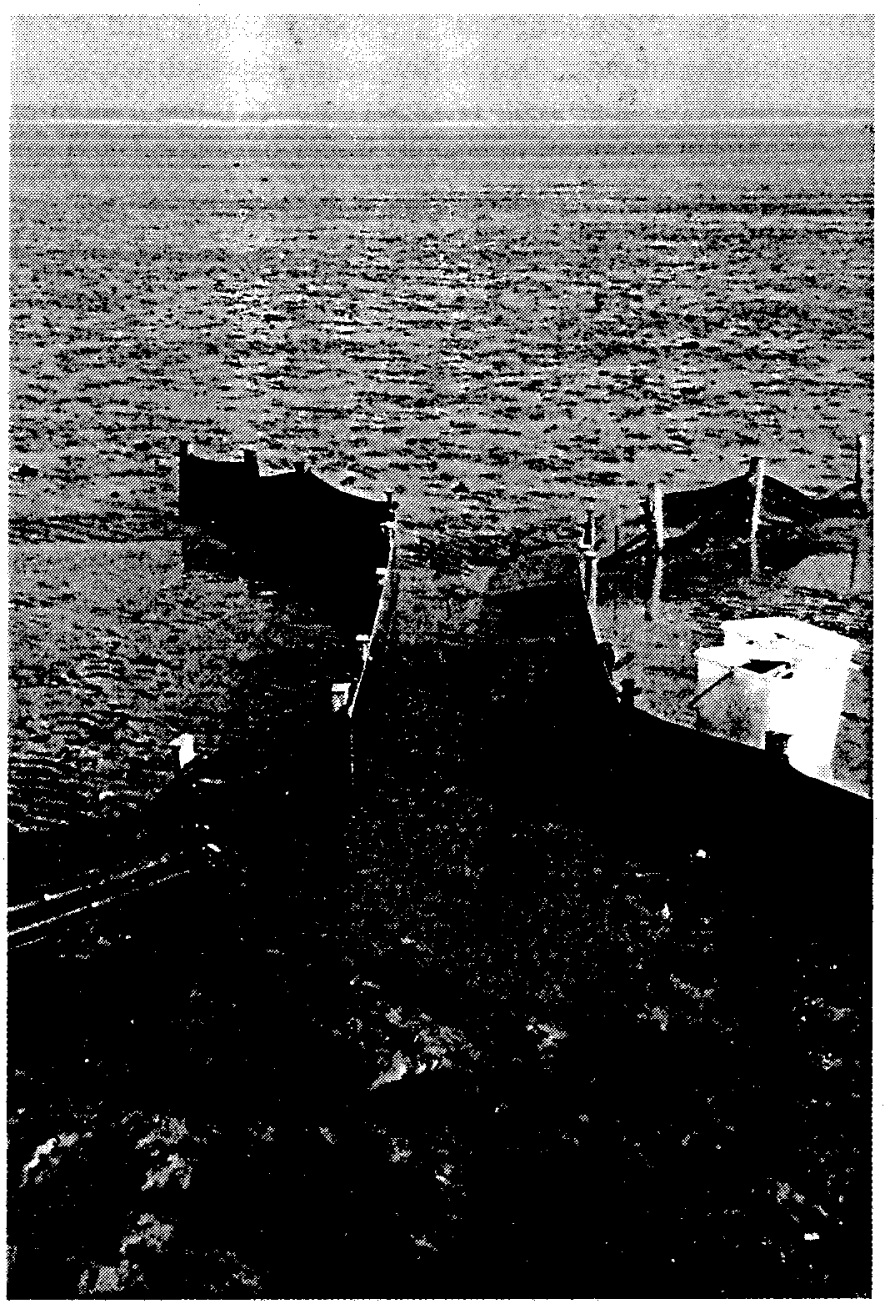

Fig. 2. Flume with funnel-shaped exits used to investigate the effect of increased sediment drift on macrofauna

surface sediment. The amount of sediment disturbance in and outside the flumes was determined by three sand tracers, respectively (see above). Re-coring of the sand tracer caused severe disturbances of sediment inside the flume. Therefore, this was done only at the end of each experiment. In the case that more than one set of samples was taken from one flume, the amount of erosion was estimated from sediment height at the flume walls. The experimental construction was erected twice at each of the two sites.

Abiotic factors were similar at both localities: current velocity varied between $7 \mathrm{~cm}$ $\mathrm{s}^{-1}$ and $18 \mathrm{~cm} \mathrm{~s}^{-1}$, median particle diameter between 0.34 and $0.36 \mathrm{~mm}$ (moderately sorted), mean organic content between $0.36 \%$ and $0.38 \%$. 
Faunal samples in and outside the flumes were taken at low tide after notable erosion was observed (Table 1). A corer of $23 \mathrm{~cm}^{2}$ cross surface was pushed to a sediment depth of $10 \mathrm{~cm}$. Within the flume 6 to 12 samples were taken randomly. Control samples were randomly taken from areas adjacent to the flume at a distance of 3 to $10 \mathrm{~m}$. Each core was fractioned and analysed as described above.

Comparisons were conducted between macrofaunal samples taken from inside and outside the flumes at the same time and between samples from flumes with different degrees of erosion. Differences of numbers of species were tested with the student-t-test, differences of numbers of individuals with the Wilcoxon-Mann-Whitney-U-test, with $\mathrm{p}<0.05$ taken as level of significance. The normal approximation to the U-test was applied when $n>20$ (Zar, 1984). Means are given with standard deviations (SD).

Table 1. Range of depth $(\mathrm{cm})$ of erosion inside the flumes and sediment disturbance (erosion and sedimentation) outside flumes at two sites in Möwenbergwatt. Erosion and sediment disturbance were determined from stained sand tracer (see text). " Erosion was estimated from sediment height at the flume walls

\begin{tabular}{|lllcrr|}
\hline & $\begin{array}{c}\text { Date of } \\
\text { erecting } \\
\text { flume }\end{array}$ & $\begin{array}{c}\text { Date of } \\
\text { measurement }\end{array}$ & $\begin{array}{c}\text { Range of } \\
\text { erosion } \\
\text { inside flume }\end{array}$ & $\begin{array}{c}\text { Range of } \\
\text { sediment } \\
\text { disturbance } \\
\text { outside flume }\end{array}$ & $\begin{array}{r}\text { Number of } \\
\text { replicates } \\
\text { for faunal } \\
\text { analysis }\end{array}$ \\
\hline Site D & & & & $1-2$ & 10 \\
Flume 1 & July 18 & July 22 & $3-4$ & $0-1$ & 8 \\
Flume 2 & August 3 & August 8 & $0-1 *$ & $1-2$ & 8 \\
Site A & & August 9 & $2-3$ & $1-2$ & 6 \\
Flume 1 & Sept. 28 & Oct. 3 & $3-4$ & $0-1$ & 6 \\
Flume 2 & Oct. 8 & Oct. 11 & $1-2 *$ & $0-1$ & 6 \\
& & Oct. 16 & $2-3^{*}$ & $1-2$ & \\
& & Oct. 22 & $3-4$ & & 6 \\
\hline
\end{tabular}

\section{RESULTS}

\section{Sediment mobility}

Throughout the study area the depth of sediment disturbance was $<3 \mathrm{~cm}$ and increased from high to low tide level (Table 2). Measurements taken during the first 10 days revealed that depth of sediment disturbance at the high and mid intertidal was significantly less than at low intertidal (ANOVA; Tukey-test, $\alpha=0.05$ ). Testing the data from 11 to 28 days resulted in a significant difference between the high and mid intertidal level. Drift distances of tracer sediments observed at the three localities supported the above results. From high to low water level, drift distances increased. At the low intertidal the dyed sand was dispersed to such a degree that even after one tide it could not be rediscovered in the field (Table 2). 
Table 2. Maximum (SD; $n$ ) depth of sediment disturbance and of horizontal distance of sediment dispersion in $\mathrm{mm}$ in Möwenbergwatt in September/October 1991. The depth of sediment disturbance was determined from stained sand columns left in the sediment for varying time intervals. Measurements were grouped into 1-10 and 11-28 days. Horizontal sediment dispersion was measured from dyed sand patches on the sediment surface left for two tides. See text for details. $\mathrm{MHW}=$ mean high water

\begin{tabular}{|rrrrr|}
\hline \multicolumn{2}{r}{$\begin{array}{r}\text { Tidal zone: } \\
\text { Depth (m) at MHW: }\end{array}$} & $\begin{array}{c}\text { High } \\
0.9\end{array}$ & $\begin{array}{c}\text { Mid } \\
1.1\end{array}$ & $\begin{array}{c}\text { Low } \\
1.7\end{array}$ \\
\hline Depth after & 1 to $10 \mathrm{~d}:$ & $2(3 ; 22)$ & $4(4 ; 11)$ & $13(7 ; 4)$ \\
& 11 to $28 \mathrm{~d}:$ & $9(6 ; 14)$ & $20(6 ; 14)$ & $18(12 ; 7)$ \\
Distance after & 2 tides: & $110(21 ; 8)$ & $579(594 ; 8)$ & $\begin{array}{c}\text { entirely } \\
\end{array}$ \\
& & & & dispersed (4) \\
\hline
\end{tabular}

\section{Macrofaunal distribution}

At three sandy sites, arranged from high to low tide zone and from low to high sediment mobility, the macrobenthic fauna generally declined in species density and abundance (Table 3). Nearly all species inhabiting the mobile sand at low tide level also occurred in the stable sediment at high tide level. On the other hand, several species found in the stable sediment were not encountered in the mobile sand. Total abundance was an order of magnitude higher at the site with low sediment mobility compared to the site with high sediment mobility, the one with moderate mobility being about midway inbetween. Differences between sites were significant at both sampling periods (U-test, $\mathrm{p}<0.05)$.

Of the 10 most abundant species the abundance of two polychaete species, Pygospio elegans and Scoloplos armiger, and two oligochaete species, Tubificoides benedii and $T$. pseudogaster, decreased with increasing sediment mobility. The small free-burrowing polychaete Microphthalmus sczelkowii was abundant in stable sediment but was absent at the other two sample sites. Counts of fecal castings showed the lugworm, Arenicola marina, to be abundant at low sediment mobility $\left(26.5 \pm 9.3 \mathrm{~m}^{-2}\right)$ and infrequent at moderate $\left(6.9 \pm 4.4 \mathrm{~m}^{-2}\right)$ and high mobility $\left(8.6 \pm 4.8 \mathrm{~m}^{-2}\right)$. No significant difference between abundance in stable and highly mobile sediment was found for the polychaete Capitella capitata. The only species with a higher abundance in mobile sand were Spio filicornis and Streptosyllis websteri. The latter was not among the 10 dominants but 22 individuals were found in mobile sediment and only occasional individuals at the other two locations.

\section{Effects of experimental erosion}

Enhanced erosion in experimental flumes at both sites caused species density and macrofaunal abundance to decrease significantly (Table 4). Overall abundance was 30 to $40 \%$ lower in flume sediment than in the control sediments outside flumes.

Testing the samples from each flume against the respective samples from ambient sediment showed significantly less numbers of individuals inside the flume on 5 out of 7 sampling dates (Fig. 3). No significant difference was found on August 8th, when 
Table 3. Species and abundance of all macrofauna $(>0.25 \mathrm{~mm})$, and of the 10 top dominants at 3 sites from high to low tide zone and from low to high sediment mobility (see Table 1) in September (S) and November (N) 1991; mean (SD) of $n=6$ samples of $100 \mathrm{~cm}^{2}$ and $10 \mathrm{~cm}$ depth. * significantly highest abundance, ${ }^{(*)}$ significantly higher than one of the other abundances

\begin{tabular}{|c|c|c|c|c|}
\hline $\begin{array}{l}\text { Tidal zone: } \\
\text { Sediment mobility: }\end{array}$ & & $\begin{array}{l}\text { high } \\
\text { low }\end{array}$ & $\underset{\text { mid }}{\text { moderate }}$ & $\begin{array}{l}\text { low } \\
\text { high }\end{array}$ \\
\hline $\begin{array}{l}\text { Species } 1200 \mathrm{~cm}^{-2} \\
\text { Species } 100 \mathrm{~cm}^{-2} \\
\text { All individuals }\end{array}$ & $\begin{array}{c}S, N \\
S \\
N \\
S \\
N\end{array}$ & $\begin{array}{c}27 \\
13.2(2.1)^{(*)} \\
14.0(2.0)^{(*)} \\
392.0(43.6)^{*} \\
185.5(38.9)^{*}\end{array}$ & $\begin{array}{c}23 \\
12.7(1.6)^{(*)} \\
12.0(1.5)^{(*)} \\
94.3(38.4)^{(*)} \\
53.7(19.3)^{(*)}\end{array}$ & $\begin{array}{c}18 \\
4.3(2.3) \\
6.2(1.6) \\
12.5(7.2) \\
14.8(6.7)\end{array}$ \\
\hline $\begin{array}{l}\text { Microphthalmus sczelkowii } \\
\text { Mecznikow } 1865\end{array}$ & $\begin{array}{l}\mathrm{S} \\
\mathrm{N}\end{array}$ & $\begin{array}{c}109.7(40.2)^{*} \\
10.7(0.8)^{*}\end{array}$ & - & - \\
\hline $\begin{array}{l}\text { Tubificoides pseudogaster } \\
\text { (Dahl 1960) }\end{array}$ & $\begin{array}{c}S \\
N\end{array}$ & $\begin{array}{l}78.3(19.8)^{*} \\
50.7(22.4)^{*}\end{array}$ & $\begin{array}{l}10.8(6.0)^{(*)} \\
16.2(10.6)^{(*)}\end{array}$ & $0 . \overline{2}(0.4)$ \\
\hline $\begin{array}{l}\text { Tubificoides benedii } \\
\text { (Udekem 1855) } \\
\text { Pygospio elegans <5 mm } \\
\text { Claparede } 1863\end{array}$ & $\begin{array}{l}\mathrm{S} \\
\mathrm{N} \\
\mathrm{S} \\
\mathrm{N}\end{array}$ & $\begin{array}{r}110.0(19.2)^{*} \\
74.0(22.6)^{*} \\
12.3(6.7)^{(\bullet)} \\
13.7(7.3)^{(*)}\end{array}$ & $\begin{array}{l}5.2(2.5)^{(*)} \\
4.5(1.4)^{(*)} \\
7.3(4.4)^{(*)} \\
3.0(2.4)^{(*)}\end{array}$ & $\begin{array}{l}1.5(2.1) \\
0.7(0.8) \\
0.8(1.6) \\
0.2(0.4)\end{array}$ \\
\hline Pygospio elegans $>5 \mathrm{~mm}$ & $\begin{array}{l}S \\
N\end{array}$ & $\begin{array}{r}13.3(7.0)^{*} \\
1.8(1.3)\end{array}$ & $\begin{array}{l}1.3(1.9) \\
0.8(0.8)\end{array}$ & $0.5(0.5)$ \\
\hline $\begin{array}{l}\text { Scoloplos armiger }<10 \mathrm{~mm} \\
\text { O. F. Müller } 1776\end{array}$ & $\begin{array}{l}\mathrm{S} \\
\mathrm{N}\end{array}$ & $\begin{array}{c}12.7(10.0)^{(*)} \\
-\end{array}$ & $\begin{array}{l}6.5(5.2) \\
0.2(0.4)\end{array}$ & $0.2(0.4)$ \\
\hline Scoloplos armiger $>10 \mathrm{~mm}$ & $\begin{array}{l}\mathrm{S} \\
\mathrm{N}\end{array}$ & $\begin{array}{r}10.3(5.4)^{*} \\
7.8(3.9)^{(*)}\end{array}$ & $\begin{array}{l}5.7(2.8)^{(*)} \\
5.8(2.4)^{(*)}\end{array}$ & $\begin{array}{l}0.2(0.4) \\
0.3(0.5)\end{array}$ \\
\hline $\begin{array}{l}\text { Macoma balthica } \\
\text { (Linné) }\end{array}$ & $\begin{array}{c}\mathrm{S} \\
\mathrm{N}\end{array}$ & $\begin{array}{l}4.2(2.4)^{(*)} \\
0.7(0.8)^{(*)}\end{array}$ & $\begin{array}{l}3.8(2.6)^{(*)} \\
2.3\left(2.7^{(*)}\right.\end{array}$ & - \\
\hline $\begin{array}{l}\text { Paranais Litoralis } \\
\text { (Müller 1784) }\end{array}$ & $\begin{array}{l}\mathrm{S} \\
\mathrm{N}\end{array}$ & $\begin{array}{l}19.2(11.7)^{(*)} \\
1.7(1.2)\end{array}$ & $\begin{array}{c}30.8(20.6)^{(*)} \\
0.2(0.4)\end{array}$ & - \\
\hline $\begin{array}{l}\text { Cerastoderma edule } \\
\text { (Linné) }\end{array}$ & $\begin{array}{c}\mathrm{S} \\
\mathrm{N}\end{array}$ & $\begin{array}{l}4.0(1.7)^{(*)} \\
7.2(1.5)^{(*)}\end{array}$ & $\begin{array}{l}5.2(4.8)^{(*)} \\
9.3(6.3)^{(*)}\end{array}$ & $\begin{array}{l}0.3(0.8) \\
0.5(0.8)\end{array}$ \\
\hline $\begin{array}{l}\text { Capitella capitata } \\
\text { (Fabricius 1780) }\end{array}$ & $\begin{array}{l}\mathrm{S} \\
\mathrm{N}\end{array}$ & $\begin{array}{r}8.3(7.8)^{(*)} \\
10.2(6.7)^{(*)}\end{array}$ & $\begin{array}{l}0.7(1.2) \\
2.2(2.1)\end{array}$ & $\begin{array}{l}2.3(2.3) \\
5.7(3.2)\end{array}$ \\
\hline $\begin{array}{l}\text { Spio filicornis } \\
\text { (O. F. Müller 1766) }\end{array}$ & $\begin{array}{c}\mathrm{S} \\
\mathrm{N}\end{array}$ & $\begin{array}{l}2.5(2.4) \\
0.8(1.0)\end{array}$ & $\begin{array}{l}2.0(2.0) \\
0.2(0.4)\end{array}$ & $\begin{array}{l}5.7(4.7) \\
3.5(2.4)^{(\bullet)}\end{array}$ \\
\hline
\end{tabular}

erosion inside and outside the flume was the same. Also no significant difference was found between samples taken after a storm (Oct. 22nd) when abundance decreased significantly in both flume and ambient sediment, in comparison to the week before.

Juveniles of the bivalve Macoma balthica, the polychaetes Pygospio elegans and Scoloplos armiger, the mudsnail Hydrobia ulvae, and adults of the polychaete Microphthalmus sczelkowii were particularly affected by erosion. Apart from the latter, all of them predominantly inhabited the upper $1 \mathrm{~cm}$ sediment layer. The entire polychaete abundance was about halved, but no significant effect was observed on Capitella 
Table 4. Species and abundance of all macrofauna $(>0.25 \mathrm{~mm})$, and of the 10 top dominants in experimentally-eroded flume sediments and ambient sediments at site D (July 22nd and August 9th; $\mathrm{n}=18$ ) and site A (October 3rd, 11th, 16th, 22nd; $\mathrm{n}=30$ ). Mean of samples of $23 \mathrm{~cm}^{2}$ and $10 \mathrm{~cm}$ depth. ${ }^{1)}$ Calculated for August 9 th $(n=8)$ only, since inadequately separated in July. * Significantly higher abundance than in flume sediment

\begin{tabular}{|c|c|c|c|c|}
\hline \multirow[b]{2}{*}{ Species } & \multirow{2}{*}{$\begin{array}{c}\text { Site } \\
\mathrm{D} \\
\mathrm{A}\end{array}$} & Flume sediment & \multicolumn{2}{|c|}{ Ambient sediment } \\
\hline & & $\begin{array}{ll}7.7 & (2.0) \\
7.9 & (1.8)\end{array}$ & & $\begin{array}{l}(0.9)^{*} \\
(1.4)^{*}\end{array}$ \\
\hline All individuals & $\begin{array}{l}\mathrm{D} \\
\mathrm{A}\end{array}$ & $\begin{array}{l}56.0(12.8) \\
55.9(17.8)\end{array}$ & $\begin{array}{l}89.4 \\
77.4\end{array}$ & $\begin{array}{l}(15.5)^{*} \\
(17.3)^{*}\end{array}$ \\
\hline Macoma balthica $<5 \mathrm{~mm}$ & D & $0.3 \quad(0.6)$ & 3.2 & $(2.7)^{*}$ \\
\hline Hydrobia ulvae & $\mathrm{D}$ & $1.2 \quad(2.2)$ & 7.2 & $(4.6)^{*}$ \\
\hline Pygospio elegans $<5 \mathrm{~mm}$ & $\begin{array}{l}\mathrm{D} \\
\mathrm{A}\end{array}$ & $\begin{array}{ll}1.9 & (2.6) \\
1.7 & (1.8)\end{array}$ & $\begin{array}{l}6.2 \\
5.7\end{array}$ & $\begin{array}{l}(6.4)^{*} \\
(3.8)^{*}\end{array}$ \\
\hline Pygospio elegans $>5 \mathrm{~mm}$ & $\begin{array}{l}\text { D } \\
\text { A }\end{array}$ & $\begin{array}{ll}0.4 & (0.9) \\
1.2 & (1.1)\end{array}$ & $\begin{array}{l}0.9 \\
2.5\end{array}$ & $\begin{array}{l}(1.2) \\
(2.1)^{*}\end{array}$ \\
\hline Scoloplos armiger $<10 \mathrm{~mm}$ & $\mathrm{D}$ & $4.6 \quad(3.7)$ & 8.7 & $(5.4)^{*}$ \\
\hline Scoloplos armiger $>10 \mathrm{~mm}$ & $\begin{array}{l}\mathrm{D} \\
\mathrm{A}\end{array}$ & $\begin{array}{ll}2.1 & (1.9) \\
1.4 & (1.4)\end{array}$ & $\begin{array}{l}4.5 \\
2.8\end{array}$ & $\begin{array}{l}(3.3)^{*} \\
(1.5)\end{array}$ \\
\hline Microphthalmus sczelkowii & A & $6.1 \quad(5.4)$ & 12.1 & $(8.3)^{\bullet}$ \\
\hline Nereis diversicolor & $\mathrm{D}$ & $3.5 \quad(2.1)$ & 5.1 & (3.3) \\
\hline Capitella capitata & $\begin{array}{l}\mathrm{D} \\
\mathrm{A}\end{array}$ & $\begin{array}{ll}2.7 & (2.2) \\
3.6 & (3.3)\end{array}$ & $\begin{array}{l}4.1 \\
3.1\end{array}$ & $\begin{array}{l}(2.6) \\
(2.2)\end{array}$ \\
\hline Paranais litoralis & $\begin{array}{l}\mathrm{D} \\
\mathrm{A}\end{array}$ & $\begin{array}{ll}2.7 & (5.1)^{1)} \\
2.0 & (2.3)\end{array}$ & $\begin{array}{l}4.3 \\
3.1\end{array}$ & $\begin{array}{l}(7.3)^{1)} \\
(2.1)\end{array}$ \\
\hline Tubificoides pseudogaster & $\begin{array}{l}\mathrm{D} \\
\mathrm{A}\end{array}$ & $\begin{array}{ll}17.1 & (9.2)^{\mathrm{n}} \\
14.5 & (6.1)^{3}\end{array}$ & $\begin{array}{l}23.1 \\
17.4\end{array}$ & $\begin{array}{l}(9.3)^{1)} \\
(7.0)\end{array}$ \\
\hline Tubificoides benedii & $\begin{array}{l}\mathrm{D} \\
\mathrm{A}\end{array}$ & $\begin{array}{ll}18.5 & '(8.1) \\
22.6 & (8.4)\end{array}$ & $\begin{array}{l}20.2 \\
25.2\end{array}$ & $\begin{array}{l}(8.1) \\
(9.0)\end{array}$ \\
\hline
\end{tabular}

capitata. In oligochaetes, no significant effect on the total number of Tubificoides benedii and Tubificoides pseudogaster was noted. It can be assumed that downward migration occurred in response to sediment erosion. In the upper $0-1 \mathrm{~cm}$ horizon the oligochaete abundance was significantly reduced inside the flume sediment (Fig. 4). In deeper horizons their abundance did not change significantly, even after erosion of up to $4 \mathrm{~cm}$ of the surface sediment. Testing the data of the flumes with $1-2 \mathrm{~cm}$ and $2-3 \mathrm{~cm}$ erosion against those with 3-4 cm erosion showed that in two of four cases significantly higher numbers of Tubificoides inhabited the horizons below $1 \mathrm{~cm}$ depth in the stronger eroded flume sediments, although there was no difference between the flumes regarding the total number of Tubificoides. A storm event on October 20th had an effect similar to experimental erosion. Abundance was particularly low at the surface but remained the same below $1 \mathrm{~cm}$ depth (Fig. 4: compare ambient sediment on October 11th and 22nd). 


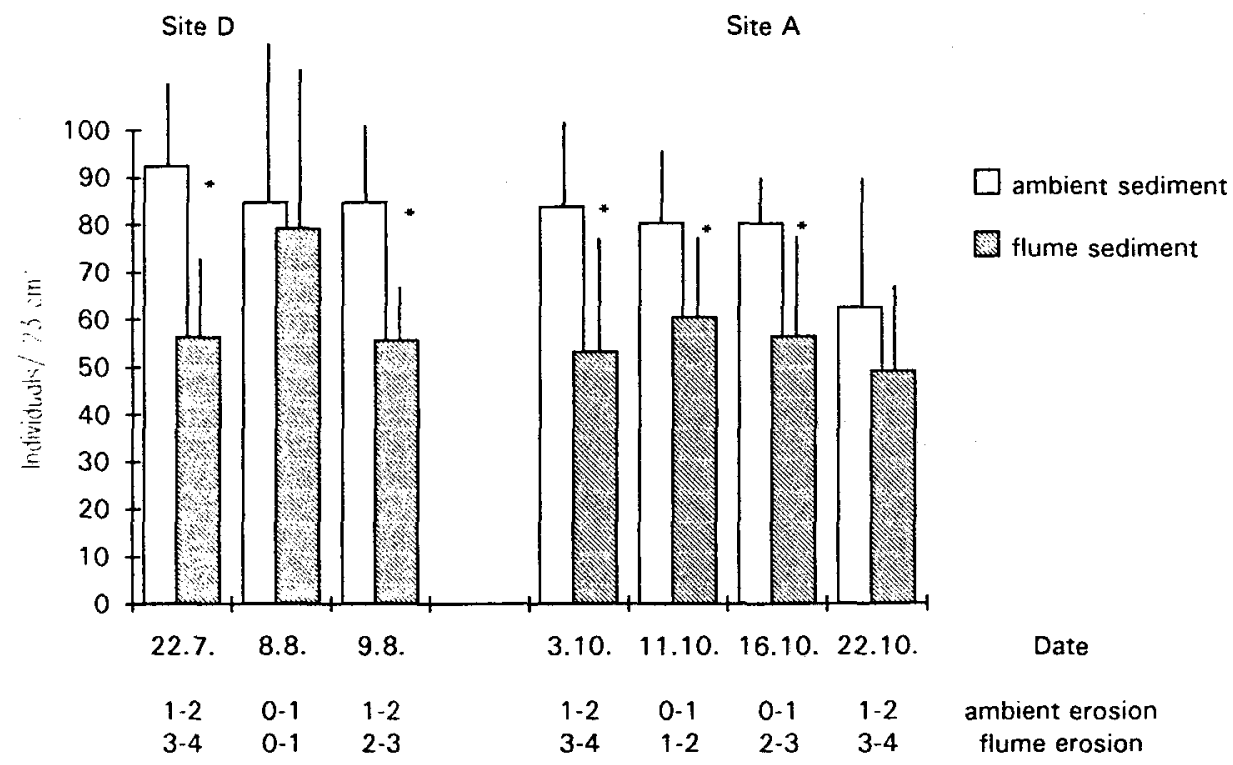

Fig. 3. Abundance (individuals $\cdot 23 \mathrm{~cm}^{-2}$ ) inside flumes and in ambient sediment at 2 sites and different dates. Depth of erosion $(\mathrm{cm})$ was measured with stained sediment and with reference to flume walls (see Table 1). * significant difference in individual abundance

\section{DISCUSSION}

\section{Sediment mobility}

The investigated Möwenbergwatt may be regarded as a low-energy sand flat. Ripples occurred only during stormy periods. The surface topography was dominated by fecal mounds and feeding funnels of lugworm burrows. This biogenic activity of Arenicola marina frequently obliterated attempts to measure hydrogenic sediment mobility with stained columns of tracer sediment. While lugworms cause considerable vertical sediment mobility (Cadée, 1976), hydrodynamic forces predominantly cause horizontal mobility. On a high-energy sand flat with ebb-dominated ripples, the depth of tidal disturbance in the sediment was $0-3 \mathrm{~cm}$, and not significantly different between high and low intertidal areas (Grant, 1981). On the low-energy sand flat investigated here, this depth varied in the same range but tended to increase from high to low tide level. On the other hand, estimates of horizontal sediment drift suggested a rather strong increase along this gradient. Drift is slow in the upper and fast in the lower intertidal. It is this facet of hydrogenic sediment mobility which appears to differentiate high- and low-energy flats as well as high and low intertidal zones most clearly. Concurrent differences in faunal distribution may therefore be influenced more by the horizontal than the vertical component of sediment mobility. 
Flume sediment

October 11

$1-2 \mathrm{~cm}$ erosion

\section{Ambient sediment}

October 11

$0.1 \mathrm{~cm}$ sediment disturbance

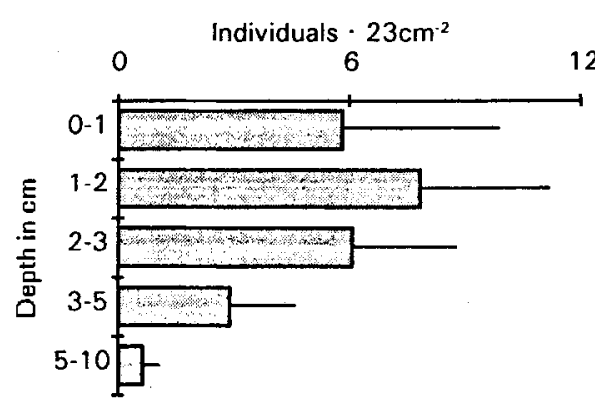

October 22

3-4 cm erosion

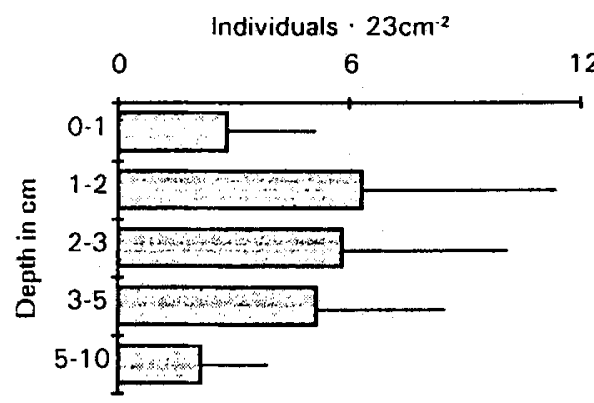

October 22 (storm)

$1-2 \mathrm{~cm}$ sediment disturbance

20

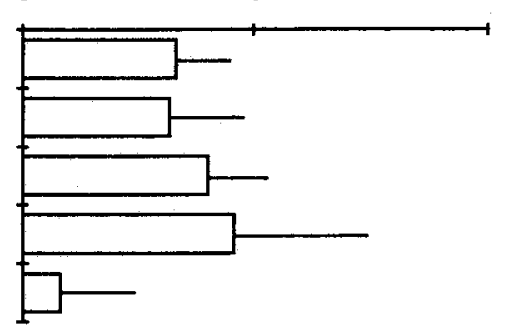

Fig. 4. Vertical distribution of Tubificoides benedii in experimentally-eroded flume sediment and ambient sediment at site $A$ on October 11th and following a storm on October 22nd

\section{Sediment mobility and macrofaunal distribution}

Similar to organisms on rocky shores, those dwelling on sedimentary tidal flats may exhibit zonal distribution patterns between the tide marks (Eltringham, 1971). These patterns are usually complex because sediment composition often changes with tidal elevation. For example, Beukema (1976) encountered most macrofauna at mid tide level where silt content was intermediate, and a decrease towards upshore mud flats and towards downshore clean sand. However, on beaches with a fairly uniform sand composition, macrofaunal abundances and species number increase in downshore direction (McIntyre \& Eleftheriou, 1968; Johnson, 1970). This pattern may be explained by higher physiological stresses associated with increasing elevation and aerial exposure. 
In Möwenbergwatt, three sites with similar sediment composition were selected along the tidal gradient. Here, the macrofaunal distribution pattern was the reverse: abundance and species number decreased in downshore direction. Thus, we have to assume one or more factors which outweigh the benefits of decreasing physiological stress in the lower intertidal. One such factor may be increased sediment mobility on sandy flats in downshore direction, as it is documented for Möwenbergwatt in this study. Another factor may be increasing epibenthic predation pressure from high to low tide level. This may produce similar effects on macrofauna, and has been documented by Reise (1978) for the same area but other habitat types (i.e. seagrass bed, mud flat).

Qualitative aspects of faunal change on sand flats in Möwenbergwatt favour the hypothesis of sediment mobility affecting the distribution pattern. While overall annelid abundance decreased significantly from the high to the low elevation site, two polychaete species showed the reverse. Spio filicornis and Streptosyllis websteri are competent swimmers (own observation). This may help them to cope with sediment mobility but is of no advantage when preyed upon by fish and shrimp. Also, Capitella capitata was not significantly less abundant at the low elevation site. This polychaete is known to populate disturbed sediments (Grassle \& Grassle, 1974; Gray, 1981) but is not resistant to epibenthic predation (Reise, 1978). Annelids with limited swimming abilities and not known to be opportunistic, such as Pygospio elegans, Scoloplos armiger and Tubificoides spp., were significantly less abundant at the low elevation site where sediment drift was fast, compared to the high elevation site with slow sediment drift.

Based on these qualitative aspects of macrofaunal distribution pattern, we propose that sediment mobility may be a key factor to abundance and species number on sheltered tidal sand flats. Hitherto, this was only suggested for shores with different degrees of wave exposure (Ansell et al., 1972; Dörjes, 1976; Oliver et al., 1980; Dexter, 1984).

\section{Macrofauna in experimentally-eroded sediment}

The flume experiment was designed to simulate high sediment mobility on a sand flat with an otherwise relatively stable sediment. This aim was only partially fulfilled. In the lower intertidal, the natural turnover of sediment particles was a fast and ongoing process with erosion and sedimentation being approximately in balance. In the experimental flume, a previously stáble sediment was subjected to a sudden disturbance where erosive processes dominated over sedimentation.

The effects on the macrobenthic fauna were similar but not identical between the natural and experimental sediment disturbance. Juvenile molluscs and small polychaetes abundant at or close to the sediment surface were rare at both the mobile sand in the lower intertidal and also the eroded sand inside the flumes. Capitella capitata remained unaffected by continuous as well as short-term disturbance.

The overall similarity of the macrofauna at a low intertidal site with permanent sediment mobility and a high intertidal site with experimentally-increased erosion indicates that differential hydrodynamic forces may contribute to the macrofaunal zonation between the tide marks. A notable difference between natural and experimental disturbance was apparent in two tubificid oligochaetes. These were rare in mobile sand of the lower intertidal but were resistant to experimental erosion. No significant losses occurred inside flumes. The oligochaetes accomplished this by downward escape within 
the sediment. This was inferred from a downward shift in the vertical distribution, revealed by stratified sampling at low tide exposure. Presumably these oligochaetes resist short-term disturbances in the surface sediment by temporary retreat to deeper sediment layers, but are unable to dwell there permanently (see Meinecke \& Westheide, 1978).

\section{CONCLUSION}

With a comparative and an experimental approach, it is shown that enhanced sediment mobility has predominantly negative effects on the macrobenthic fauna. However, tubificid oligochaetes are able to resist short-term disturbance; the polychaete Capitella capitata withstands also permanent disturbances of the upper sediment layer, and Spio filicornis seems to be specifically adapted to fast sediment drift. This study indicates that even in a low-energy sedimentary environment, sediment mobility affects the distribution of the benthic fauna.

Acknowledgements. We thank Ingrid Austen (Forschungs- und Technologiezentrum Westküste der Universität Kiel, Büsum) for supplying us with stained sand, and all those people who helped to erect the flumes. This study was conducted as part of the project "Ecosystem research Wadden Sea", (publication no. 122), supported by the Federal Ministries for Research and Technology (BMFT) and the Environment (BMU/UBA) and the state of Schleswig-Holstein.

\section{LITERATURE CITED}

Ansell, A. D., Sivadas, P., Narayanan, B., Sankaranarayanan, V. N. \& Trevallion, A., 1972. The ecology of two sandy beaches in south-west India. - Mar. Biol. 17, 38-62.

Austen, I., 1992. Geologisch-sedimentologische Kartierung des Königshafens (List/Sylt). - Meyniana $44,45-52$.

Beukema, J. J., 1976. Biomass and species richness of the macro-benthic animals living on the tidal flats of the Dutch Wadden Sea. - Neth. J. Sea Res. 10, 236-261.

Brey, T., 1991. The relative significance of biological and physical disturbances: an example from intertidal and subtidal sandy communities. - Estuar. coast. Shelf Sci. 33, 339-360.

Cadée, G. C., 1976. Sediment reworking of Arenicola marina on tidal flats in the Dutch Wadden Sea.Neth. J. Sea Res. 10, 440-460.

Croker, R. A., 1977. Macroinfauna of northern New England marine sand: long-term intertidal community structure, In: Ecology of marine benthos. Ed. by B. C. Coull. Univ. South Carolina Press, Columbia, 439-450.

Dexter, D. M., 1984. Temporal and spatial variability in the community structure of the fauna of four sandy beaches in south-east New South Wales. - Aust. J. mar. Freshwat. Res. 35, 663-672.

Dörjes, J., 1976. Primärgefüge, Bioturbation und Makrofauna als Indikatoren des Sandversatzes im Seegebiet vor Norderney (Nordsee). II. Zonierung und Verteilung der Makrofauna. - Senckenberg. marit. $8(4 / 6), 171-188$.

Ehlers, J., 1988. The morphodynamics of the wadden sea. Balkema, Rotterdam, $397 \mathrm{pp}$.

Eltringham, S. K., 1971. Life in mud and sand. Crane, Russak \& Comp., New York, 218 pp.

Grant, J., 1981. Sediment transport and disturbance on an intertidal sandflat: infaunal distribution and recolonisation. - Mar. Ecol. Prog. Ser. 6, 249-255.

Grant, J., 1983. The relative magnitude of biological and physical sediment reworking in an intertidal community, - J. mar. Res. 41, 673-689.

Grassle, J. F. \& Grassle, J. P. 1974. Opportunistic life histories and genetic systems in marine benthic polychaetes. - J. mar. Res. 32, 253-284.

Gray, J. S., 1981. The ecology of marine sediments. Cambridge Univ. Press, Cambridge, 185 pp.

Ingle, J. C., 1966. The movement of beach sand. Elsevier, New York, $221 \mathrm{pp}$. 
Johnson, R. G., 1970. Variations in diversity within benthic marine communities. - Am. Nat. 104, 285-300.

McIntyre, A. D. \& Eleftheriou, A., 1968. The bottom fauna of a flatfish nursery ground. - J. mar. biol, Ass. U.K. $48,113-142$.

Meineke, T. \& Westheide, W., 1979. Gezeitenabhängige Wanderungen der Interstitialfauna in einem Sandstrand der Insel Sylt (Nordsee). - Mikrofauna Meeresboden 75, 1-36.

Oliver, J. S., Slattery, P. N., Hulberg, L. W. \& Nybakken, J. W., 1980. Relationship between wave disturbance and zonation of benthic invertebrate communities along a subtidal high-energy beach in Monterey Bay, California. - Fish. Bull. 78, 437-454.

Postma, H., 1982. Hydrography of the Wadden Sea: movements and properties of water and particulate matter. In: Ecology of the Wadden Sea. Ed. by W. J. Wolff. Balkema, Rotterdam, $75 \mathrm{pp}$.

Rachor, E. \& Gerlach, S. A., 1978. Changes of macrobenthos in a sublittoral sand area of the German Bight, 1967 to 1975. - Rapp. P.-v. Réun. Cons. int. Explor. Mer 172, 418-431.

Reise, K., 1978. Experiments on epibenthic predation in the Wadden Sea. - Helgoländer wiss. Meeresunters. 31, 55-101.

Reise, K., 1985. Tidal flat ecology. - Ecol. Stud. 54, 1-191.

Rhoads, D. C. \& Young, D. K., 1971. Animal-sediment relations in Cape Cod Bay, Massachusetts. II. Reworking by Molpadia oolitica (Holothuroidea). - Mar. Biol. 11, 255-261.

Rhode, B., 1985. Langfristige Bestandsänderungen der makrobenthischen Fauna im Watt bei Norderney: non-dominante Arten. - Jber. ForschSt. Küste, Norderney 37, 147-174.

Runte, K. H., 1989. Methodische Verfahren zur Quantifizierung von Umlagerungen in intertidalen Sedimenten. - Meyniana 41, 153-165.

VanBlaricom, G. R., 1982. Experimental analysis of structural regulations in a marine sand community exposed to oceanic swell. - Ecol. Monogr. 52, 283-305.

Yeo, R. K. \& Risk, M. J., 1979. Intertidal catastrophes: effect of storms and hurricanes on intertidal benthos of the Minas Basin, Bay of Fundy. - J. Fish. Res. Bd Can. 36, 667-669.

Zar, J. H., 1984. Biostatistical analysis. Prentice-Hall, Englewood Cliffs, 718 pp. 